\title{
Denetim Sürecinde Eğitim Denetmenlerinin Davranışları
}

\author{
Yrd. Doç. Dr. Süleyman GÖKSOY \\ Düzce Üniversitesi \\ Eğitim Fakültesi \\ goksoys@hotmail.com
}

\author{
Doç. Dr. Engin ASLANARGUN \\ Düzce Üniversitesi \\ Eğitim Fakültesi \\ enginaslanargun@gmail.com
}

Özet: Bu araştırmanın amacı, illerde görev yapan eğitim denetmenlerinin görevlerini yerine getirirken ön plana çıkan davranışlarını tespit etmektir. Nitel araştırma yöntemlerinden olgubilim desenine göre yürütülen araştırma kapsamında 47 eğitim denetmeni ile çalışılmıştır. Veriler değişik illerde görev yapan eğitim denetmenlerinden gönüllü olanların doldurduğu görüşme formları aracılığı ile toplanmış, betimsel ve içerik analizine tabi tutulmuştur. Bu Araştırma sonucunda eğitim denetmenliği mesleğinde iletişim ve liderlikle ilgili kavramlar ön plana çıkmaktadır. Denetmenlerin büyük bir çoğunluğunun bu kavramlara vurgu yapması sahip olunması gereken ve eksikliği çekilen davranışlara ilişkin önemli bilgiler sunmaktadır. Özellikle son yıllarda denetimden rehberliğe doğru anlayış değişikliğinin yaşandığı bir ortamda bu kavramların vurgulanması anlamlıdır.

Anahtar Sözcükler: Eğitim denetmeni, eğitim denetmeni davranışları

\section{Behaviours of Supervisors in the Process of Supervision}

\begin{abstract}
The purpose of this study is to define behaviours of supervisors while performing their tasks in provinces. It was included 47 educational supervisors, and qualitative research design of phenomenology was employed in the research. The data was collected from the volunteer supervisors who were in charged of different provinces in Turkey via interview form and made descriptive and content analysis. It was concluded that concepts related with communication and leadership came into forefront. Due to the fact that supervisors have primarily emphasized on such concepts, these are the behaviours that supervisors should adapt first while doing their tasks. It is meaningful to have stressed communication and leadership when there is tendency towards guidance based supervision from control based supervision recently.
\end{abstract}

Key Words: Educational supervisor, behaviours of educational supervisor 


\section{GiRiş}

Türkiye'de eğitim denetimi Milli Eğitim Bakanlığı merkez örgütü içerisindeki Rehberlik ve Denetim Başkanlığı ile taşrada il Milli Eğitim müdürlükleri bünyesinde yer alan eğitim denetmenleri başkanlığı tarafından yerine getirilmektedir (MEB). Bakanlık bünyesinde yer alan denetçilerle il milli eğitim müdürlüklerinde görev yapan denetmenlerin seçilmeleri, atanmaları ve yetiştirilmelerine ilişkin usul ve esaslar tüzükle ve yönetmeliklerle (Resmi Gazete, 1993a; Resmi Gazete, 1993b; Resmi Gazete, 2011a) düzenlenmektedir. Bu metinlerde atanma şartlarına sahip olabilmek için bazı genel özelliklerden söz edilmekte, seçilme ölçütleri, sınava ilişkin uygulamalar, görev ve yetkiler, yetiştirilme ve görevden uzaklaştırılma ile denetime ilişkin diğer usul ve esaslar yer almaktadır. 2011 yılında bakanlık örgüt yapısında önemli değişiklikler içeren kanun düzenlemesi (Resmi Gazete, 2011b) ile denetim sistemi için de bazı yenilikler getirilmiştir. Buna göre Bakanlık merkez örgütünde görev yapan müfettişler Rehberlik ve Denetim Başkanlığı bünyesinde denetçi olarak anılmış, önleyici, eğitici ve rehberlik yaklaşımını ön plana çıkaran bir anlayışla, bakanlığın görev ve yetkileri çerçevesinde denetim, inceleme ve soruşturmalar yapmakla görevlendirilmiştir. Bu kanunda altı çizilen en önemli yenilik bakanlık denetçi yardımcılığından denetçiliğe geçebilmek için sınavda başarılı olma şartına ilaveten tez hazırlama ve kamu personeli yabancı dil sınavından C düzeyinde yeterli olma zorunluluğu getirilmiş, bu şartları yerine getirmeyenlerin denetçi yardımcılı̆̆ unvanını kaybedeceği ifade edilmiştir. İllerde görev yapan denetmenler ise ildeki her derece ve türdeki örgün ve yaygın eğitim kurumları ile il ve ilçe millî eğitim müdürlüklerinin rehberlik, işbaşında yetiştirme, denetim, değerlendirme, inceleme, araştırma ve soruşturma hizmetlerinden sorumludur.

\section{Problem Durumu}

Yapılan araştırmalarda (Lillis, 1992, 5; Badavan, 1994, 39; UNESCO, 2007, 13; Kayıkçı ve Şarlak, 2009; Yavuz ve Yıldırım, 2009; Seylim, 2009; Aksu ve Mulla, 2009; Yaman, 2009, 115; Samancı, Taşçıŏlu ve Çetin, 2009) öğretmenlerin genel anlamda denetim sistemine yönelik sahip olduğu olumsuz düşüncelerinin, denetim hizmetlerini yürüten denetmenlerin tavır ve davranışlarından bağımsız değerlendirmek mümkün değildir. Denetmenlerin denetim esnasında sergilediği davranışlar ve öğretmenlere yönelik sahip oldukları tutumlar ile bu tutum ve davranışlara kaynaklık eden davranışlar mevcut denetim ikliminin şekillenmesi ve algılanması ile yakından ilgilidir. Özellikle rehberlik ve işbaşında yetiştirme görevleri de düşünüldüğünde, yüz yüze gerçekleşen ve karşııklı etkileşim içeren bir sürecin önemi daha iyi 
anlaşılmaktadır. İnsanlar arası karşılıklı etkileşimin, rehberliğin ve bilgi paylaşımının olduğu ortamlarda kişilerin sahip olduğu davranışlar iletişim sürecine rengini veren en önemli niteliklerdendir. Bu nitelikler güven, samimiyet, empati, etik ilkeler, adalet, uzmanlık gibi toplum tarafından önem verilen davranışlar olabileceği gibi denetmenlerin atanma sürecinde altı çizilen mesleki statülerinin gerektirdiği saygınlık, güven duygusu ve tarafsızlık gibi özellikler de olabilir.

Öğretmen denetimi genel olarak teknik yeterlikler çerçevesinde, bazı metot ve ölçütlerle yanlış bir bilimsel anlayışla yürütülmektedir. Önceden belirlenmiş kuralların yerine getirilmesi ve davranışların sergilenmesi temelinde formlar aracılığıyla bazı değerlendirmelerin ve ölçümlerin yapılması esasına dayanmaktadır (Sergiovanni, 1977, 603). Denetmenlerin görev tanımı en doğru ifade ile "mesleklerini daha iyi yapabilmeleri için öğretmenlere ve okul personeline yardımcı olmak" şeklinde yapılmaktadır. Fakat aynı zamanda denetmenlerin görev tanımları ve rollerine ilişkin karmaşanın diğer sektörlere göre eğitimde daha fazla yaşandı̆̆ı da altı çizilen hususlar arasındadır (Oliva ve Pawlas, 2004, 4). Öğrenmeyi sağlama, örgütsel gelişmeyi sürdürme, hedef kitlesine yönelik saygı, gösterme, değer verme, program bütünlüğünü ve etkililiğini sağlama, en üst düzeyde memnuniyet ve başarı sağlama gibi amaç ifadeleri gelişmiş ülkelerin eğitim denetimi misyon ifadelerini oluşturmakta, temel davranışlar olarak mükemmellik, hesap verebilirlik ve bütünlük ön plana çıkmaktadır (OIG, 2005).

Eğitim sürecinde denetim uygulamalarının etkililiği ve verimliliğinde denetmen davranışları da önemli bir etken olduğu için mevcut çalışma ile illerde görev yapan eğitim denetmenlerinin görevlerini yerine getirirken ön plana çıkan denetmen davranışlarına ilişkin eğitim denetmenlerinin görüşlerini tespit edilmesi amaçlanmıştır. Araştırmada aşağıdaki sorulara cevap aranmıştır:

Yukarıda da belirtildiği gibi eğitim sürecinde amaca hangi ölçüde ulaşıldığııın, hangi ölçüde ulaşılmadığının bilinebilmesi öncelikle değerlendirme ve denetim ile mümkündür. Denetim sürecinin niteliğini belirleyen temel değişkenlerden biri de denetmen davranışlarıdır. $\mathrm{Bu}$ nedenle eğitim denetmenlerinin denetim sürecinde sergiledikleri davranışları ile göstermeleri gereken davranışlar hakkında görüşlerinin tespit edilmesi amaçlanmıştır. Araştırmada aşağıdaki sorulara cevap aranmıştır:

1. Eğitim denetmenleri görevlerini yerine getirirken sergiledikleri davranışları nelerdir?

2. Eğitim denetmenlerinin sahip olması gereken davranış ve nitelikleri nelerdir? 


\section{YÖNTEM}

\section{Araştırmanın Modeli}

Araştırmada, nitel araştırma yöntemlerinden durum çalışması kullanılmıştır. Durum çalışması araştırmacının "neden?" ve "nasıl?" sorularına odaklanarak "hedeflenen durumu" derinlemesine ve ayrıntılı olarak irdelemek istediğinde kullanılmaktadır. (Yin, 2003). Nitel durum çalışmalarında ise bir ya da birkaç durum derinlemesine araştırılarak, bir duruma ilişkin etkenler (ortam, bireyler, olaylar, süreçler vb) bütüncül bir yaklaşımla değerlendirilir ve ilgili durumu nasıl etkiledikleri ve ilgili durumdan nasıl etkilendikleri üzerine odaklanılır (Yıldırım, Şimşek, 2005). Bu amaçla alt analiz birimlerinden ayrı ayrı elde edilen verilerden yola çıkılarak, araştırma durumunun bütününe ilişkin sonuçlar üretilmeye çalışılmıştır. Bu amaçla alt analiz birimlerinden ayrı ayrı elde edilen verilerden yola çıkılarak, araştırma durumunun bütününe ilişkin sonuçlar üretilmeye çalışılmıştır.

\section{Çalışma Grubu}

Araştırma İstanbul ilinde görevli 47 il eğitim denetmeninin katılımıyla gerçekleştirilmiştir. Araştırmaya katılan eğitim denetmeni maksimum çeşitlilik örneklemesi ile belirlenmiştir. Maksimum çeşitlilik örneklemesi göreli olarak küçük bir örneklem oluşturarak bu örneklemde çalısıllan probleme taraf olabilecek bireylerin çeşitliliğini maksimum derecede yansıtmaktır (Yıldırım ve Şimşek, 2005). Araştırma örneklem grubun oluşturan 47 eğitim denetmeni belirlenirken her bir denetim grubundan en az bir eğitim denetmeninin alınmasına dikkat edilmiştir. Böylece çalışma grubu evrenin yüzde 20'sini oluşturmuş ve her beş denetmenden biri araştırmaya katılmıştır. Araştırmaya katılan eğitim denetmenleri ile yüz yüze ortalama 20 ile 30 dakika arasında bir sürede görüşülmüştür. Araştırma verileri, eğitim denetimlerinin mesleki davranışları hakkında veri toplamayı amaçladığından ve gönüllü katıııma dayandığından nitel araştırma yöntemlerinden kolay ulaşılabilir örnekleme yöntemi seçilmiştir. Katılımcı bilgileri Tablo 1' de sunulmuştur.

Tablo 1: Eğitim Denetmenlerine Ait Kişisel Bilgiler

\begin{tabular}{llcc}
\hline Değişkenler & Alt Kategoriler & $\mathbf{f}$ & $\mathbf{\%}$ \\
\hline \multirow{2}{*}{ Cinsiyet } & Kadın & 10 & 21 \\
& Erkek & 37 & 79 \\
\hline \multirow{4}{*}{ Eğitim Durumu } & Önlisans & 1 & 2 \\
& Lisans & 25 & 53 \\
& Y. Lisans & 18 & 39 \\
& Doktora & 3 & 6 \\
\hline \multirow{2}{*}{ Yaş } & $20-30$ & 1 & 2 \\
& $31-40$ & 10 & 21
\end{tabular}




\begin{tabular}{llcc} 
& $41-50$ & 22 & 47 \\
& 50 ve üzeri & 14 & 30 \\
\hline \multirow{3}{*}{ Öğretmenlik } & $1-5 \mathrm{yıl}$ & 3 & 6 \\
Hizmet Yılı & $6-10 \mathrm{yıl}$ & 11 & 24 \\
& $11-15 \mathrm{yıl}$ & 24 & 51 \\
& $16-20 \mathrm{yıl}$ & 9 & 19 \\
\hline \multirow{3}{*}{ Denetmenlik } & $1-5 \mathrm{yıl}$ & 11 & 24 \\
Hizmet Yılı & $6-10 \mathrm{yıl}$ & 1 & 2 \\
& $11-15 \mathrm{yıl}$ & 16 & 34 \\
& $16-20 \mathrm{yıl}$ & 19 & 41 \\
\hline
\end{tabular}

Tablo 1'deki veriler incelendiğinde katılımcıların çoğunluğunu erkek denetmenlerin oluşturduğu görülmektedir. Eğitim durumu açısından denetmenlerin yarısı lisans mezunu iken yüksek lisans mezunlarının oranı yüzde 40 düzeyinde yer almaktadır. Yaş değişkeni açısından katılımcıların çoğunluğu 40 yaş ve üzeri gruplarda yer almaktadır. Eğitim denetmenlerinin yarısı 11-15 yıl arası öğretmenlik deneyiminden sonra denetmenliğe başlamış ve denetmenlerin yüzde 40’ yaklaşık 20 yıldır denetim görevini sürdürmektedir.

\section{Veri Toplama Aracı}

Çalışma konusu hakkında derinlemesine bilgi edinmek için iki araştırmacı tarafından yarı yapılandırılmış açık uçlu görüşme formu hazırlanmıştır. Görüşme formu hazırlama sürecinde ayrıntılı literatür taraması yapılmış ve eğitim denetmenlerinin davranışlarına ilişkin önemli kavramlar tespit edilmiştir. Görüşme formu eğitim denetimi görevini yürüten üç eğitim denetmeni ile eğitim yönetimi, teftişi, planlaması ve ekonomisi alanında çalışan üç öğretim üyesinin görüşüne sunularak uygulama öncesi kapsam ve görünüş geçerliği açısından test edilmiştir. Ayrıca üç eğitim denetmeni ile ön deneme (pilot çalışma) uygulaması yapıımıştır. Bu işlemler sonucunda beş sorudan oluşan açık uçlu yarı yapılandırılmış soru formu elde edilmiştir. Görüşme formu soruları şu şekilde dile getirilmiştir.

Araştırmada aşağıdaki sorulara cevap aranmıştır:

1. Eğitim denetmenlerinin alan ve mevzuat bilgisi dışında sahip olması gereken davranışlar ve nitelikler nelerdir?

2. Eğitim denetmenlerini güçlü kılan özellikler nelerdir?

3. Eğitim denetmenleri görevlerini yerine getirirken etki/baskı altında kaldıkları durumlar nelerdir?

4. Öğretmenleri rahatsız eden denetmen davranışları nelerdir? 
5. Eğitim denetmenlerinin davranışsal açıdan örneklik sergilenmede gelişime açık alanları nelerdir?

\section{Verilerin Analizi}

Verilerin analizinde içerik analiz tekniği kullanılmıştır. Buna göre katılımcılardan form aracılığıyla elde edilen veriler düzenlenerek kodlanmış, kodlanan verilerden temalar oluşturulması yoluna gidilmiş ve bu doğrultuda bulgular tanımlanmış ve yorumlanmıştır. Analiz edilen formlara sıra numaraları verilerek doğrudan alıntıların sonunda parantez içerisinde gösterilmiş, katılımcılara ait özel sayılabilecek bilgilerin gizlenmesine özen gösterilmiştir. Kavramsal çerçeve ile uyumlu veriler bulgular halinde tanımlanmıştır. ỉki araştırmacı tarafından bağımsız olarak yürütülen analizler sonunda uyuşum oranı yüzde seksen olarak tespit edilen ortak kavramlar ve temalar araştırma bulguları olarak sunulmuştur. Araştırmacıların ortak uyuşmadıkları tema ve kodalar araştırma bulguları dışında tutulmuştur. Doğrudan alıntı olarak verilen eğitim denetmenlerinin görüşlerinde, D1, D2, ...gibi kodlar kullanılmıştır.

\section{Geçerlik ve Güvenirlik}

Nitel araştırmada "geçerlik" bilimsel bulguların doğruluğu, "güvenirlik" ise bilimsel bulguların tekrarlanabilirliği ile ilgilidir (Yıldıım ve Şimşek, 2005). Araştırmanın iç geçerliğini (inandırıcılığını) artırmak için görüşme formu geliştirilirken ilgili literatür incelemesi sonucunda konu ile ilgili bir kavramsal çerçeve oluşturulmuştur. Görüşme sonrası kişilerin söyledikleri yazılı hale dönüştürülmüş ve bu metin ilgili kişilere tekrar okutularak kontrol etmeleri istenmiş, böylece katılımc teyidi alınmıştır. Yapılan içerik analizinde temalar ve temaları oluşturan alt temaların kendi aralarındaki ilişkisi ile her bir temanın diğerleriyle ilişkisi kontrol edilerek bütünlük sağlanmıştır. Ayrıca araştırma kapsamına görüşülen eğitim denetmenlerinin denetmen yardımcısı olmamasına dikkat edilmiştir. Böylece görüşme sürecinde toplanan verilerin gerçek durumu yansıtmasına çalışılıştır. Araştırmanın dış geçerliğini (aktarılabilirliğini) artırmak için araştırma süreci ve bu süreçte yapılanlar ayrıntılı bir şekilde açıklanmaya çalışımıştır. Araştırmanın iç güvenirliğini (tutarlığını) artırmak için bulguların tamamı yorum yapılmadan doğrudan verilmiştir. Ayrıca görüşmede katılımcıları etkilememeye ve yönlendirmemeye çalışımıştır. Araştırmanın dış güvenirliğini (teyit edilebilirliğini) artırmak için araştırmacı, süreçte yapılanları ayrıntılı bir biçimde tanımlamıştır. Elde edilen ham veriler araştırmacı tarafından muhafaza edilmiştir. 


\section{BULGULAR VE YORUMLAR}

Bu bölümde belirlenen temalar ve ortaya çıkan kavramlar çerçevesinde eğitim denetmenlerinin görüşlerine yer verilmiştir. Eğitim denetmenlerinin sahip olması gereken nitelikler, denetmenleri güçlü kılan özellikler, denetim sistemine yönelik öğretmen bakış açısının şekillenmesinde denetmenlerin etkisi, denetmenlerin öğretmenlere örneklik sergileyemediği alanlar gibi konulardaki görüşler başlıklar altında sunulmakta ve arka planda yer alan davranışların tespit edilmesi hedeflenmektedir. Ortaya çıkan temalar başlıklar halinde ve doğrudan alıntılar eşliğinde araştırma soruları çerçevesinde yorumlanmaktadır. Ana kategoriler aşağıda sunulmaktadır.

$\checkmark$ Eğitim denetmenlerinin davranışları ve nitelikleri

$\checkmark$ Eğitim denetmenlerini güçlü kılan özellikler

$\checkmark$ Görev esnasında etki/baskı altında kalınan durumlar

$\checkmark$ Öğretmenleri rahatsız eden denetmen davranışları

$\checkmark$ Örneklik sergilenmede gelişime açık alanlar

\section{Eğitim Denetmenlerinin Davranışları ve Nitelikleri}

Eğitim denetmenlerinin alan ve mevzuat bilgisi dışında sahip olması gereken davranışlar ve nitelikler bu başıı altında incelenmektedir. Denetmenlerin kendi bakış açılarıyla bir denetmende olması gerektiğine inandıkları davranışları ve nitelikleri sunmaları içten bir bakışı yansıtması açısından önemlidir. Denetmenlerin alan ve mevzuat bilgisi gibi mesleki zorunluluk olan hususların dışındaki nitelikler üzerinde yoğunlaşmalarını sağlamak amaçlanmıştır. Alan ve mevzuat bilgisi dışında eğitim denetmenlerinin sergilemesi gereken davranışlar ile sahip olmaları gereken nitelikler Tablo $2^{\prime}$ de sunulmaktadır.

Tablo 2: Eğitim Denetmenlerinin Nitelikleri ve Davranışları

\begin{tabular}{ll} 
Ana Temalar & Alt Temalar \\
\hline İletişim Becerisi $(\mathrm{n}=21)$ & $\begin{array}{l}\text { Insan ilişkileri } \\
\text { Empati }\end{array}$ \\
\hline Kişisel Özellikler ( $\mathrm{n}=19)$ & Model olma \\
& Hitabet yeteneği \\
& Bakımlı ve düzenli giyinme \\
& Türkçeyi etkili kullanma \\
& Sosyal, kültürel normlara uyma \\
& Mesleki etik kuralları \\
\hline Tarafsız ve Önyargısız Olma $(\mathrm{n}=7)$ & Objektif olma \\
& Peşin hükümlü olmama \\
\hline
\end{tabular}


Tablo 2'de ortaya çıkan temalar incelendiğinde eğitim denetmenlerinde olması gereken nitelikler ve sergilemeleri gereken davranışlar iletişim becerisi, kişilik özellikleri ve tarafsızlık/önyargısız olma kavramları çerçevesinde şekillenmektedir. Eğitim denetmenlerinin kişisel ve sosyal özelliklerin altını çizdiği görülmektedir.

Illetişim Becerisi. Bu tema altında sırasıyla insan ilişkileri, hoşgörü ve empati vurgulanmaktadır. Bu alt kategorilere ilişkin katılımcı görüşlerinden bazıları şöyledir:

“...iyi bir iletişim uzmanı olmalı..." (D 1)

“...ben dilini kullanmalı..." (D 2)

“...müfettişlerin insan ilişkileri, sosyal psikoloji, eğitim bilimleri alanlarında yetkin ve yeterli olmaları" (D 12)

Eğitimci olmanın özünü ve temelini oluşturan iletişim becerisi denetim mesleği açısından artı bir davranış yerine olmazsa olmaz bir özellik olarak görülmesi, vurgulanması ve ön plana çıkarılması kurum kültürü açısından dikkate alınması gereken bir husustur.

Kişisel Özellikler. Eğitim denetmenlerinin kişisel açısından bazı niteliklere sahip olması gerektiği yine denetmenlerce dile getirilmektedir. Bunlar içerisinde denetmenlerin model olması, hitabet yeteneği, bakımlı ve düzgün giyinmesi, Türkçeyi etkili kullanması, sosyalkültürel normlara uyması ve mesleki etik ve görgü kuralları doğrultusunda hareket etmesinin altı çizilmektedir. Bu durumu açıklayan katılımcı görüşlerinden bazıları şöyledir:

"...müfettişler mutlaka protokol bilgisi ve davranışına sahip olmalı, eğitim müfettişlerinin en önemli eksikliği budur" (D 22)

“...farklılıkları anlayacak bir değer sistemini benimsemek” (D 28)

“... herkesin güven duyabilmesi, çevresindekilerin ve birlikte görev yaptığı kişilerin güvenebileceği, yalansız," (D 32)

“... klyafetine ve sözlerine özen göstermesi” (D 33)

Doğrudan alıntılarda dile getirilen müfettişlerde olması gereken kişisel özellikleri "...iyi bir insanda bulunması gerekli olan tüm davranış ve niteliklere sahip olması gerekir" ifadesi ile kapsamlı ve öz bir şekilde açıklamaktadır. 
Tarafsız ve Önyargısız Olma. Objektif olma ve peşin hükümlülükten uzak davranma eğitim denetmenlerinin sahip olması gereken nitelikler arasında sayılmaktadır. Bu durumu açıklayan katıımcı görüşlerinden bazıları şöyledir:

“...ufku geniş olmalı. Saplantısız olmalı" (D 24)

“...her şeyden önce önyargılı olmamalı ve davranmamalı..." (D 27)

“...güvenli, tarafsız ve meslek disiplinine sahip...” (D 36)

Denetim mesleği açısından tarafsızlık ve önyargısız olma en temel zorunluluktur. Böyle bir davranışların ön plana çıkması denetmenlerin temel davranışlarının geçerliliğini koruduğu ve sürdürülmeye çalışıldığının bir göstergesi sayılabilir.

\section{Eğitim Denetmenlerini Güçlü Kılan Özellikler}

Eğitim denetmenlerinin alan ve meslek bilgisi dışında kendilerini güçlü kılan özellikler bu başlık altında incelenmektedir. Denetmenlerin kendi bakış açılarıyla alan ve mesleki bilgisi dışında kendilerini güçlü kıldığını düşündüğü ve belirttiği nitelikler Tablo $3^{\prime}$ de sunulmaktadır.

Tablo 3: Eğitim Denetmenlerini Güçlü Kılan Nitelikler

\begin{tabular}{ll}
\hline Ana Temalar & Alt Temalar \\
\hline & $\begin{array}{l}\text { Empatik davranma } \\
\text { Yüz yüze iletişim }\end{array}$ \\
& \\
\hline Kişisel Özellikler $(\mathrm{n}=16)$ & \\
& Değer yargılarına saygı \\
& Sempatik ve esprili olma \\
& Özgüven \\
& Alçakgönüllülük \\
& Samimiyet \\
& Güleryüz \\
\hline Teknik Bilgi $(\mathrm{n}=13)$ & Karar verme \\
& Yeterlilik \\
& Kavrama becerisi \\
& Problem çözme becerisi \\
\hline Tarafsızlık $(\mathrm{n}=9)$ & Hakkaniyete uyma \\
\hline
\end{tabular}

Tablo 3'de eğitim denetmenlerinin kendilerini güçlü kıldığını düşündükleri nitelikler sosyal beceriler, kişisel özellikler, teknik bilgi ve tarafsızık kavramları çerçevesinde şekillenmektedir. 
İletişim Becerisi: Eğitim denetmenlerinin iletişim becerisi teması altında, empatik davranma ve yüz yüze iletişimin önemi vurgulanmaktadır. Bu durumu açıklayan katılımcı görüşlerinden bazıları şöyledir:

“...birebir iletişimi tercih ederek olumsuz durumları olumluya çevirebilirim” (D 30)

“...karşımdaki kişiyle saygıya dayalı bir iletişim kurarak durumunu anlamaya çalışırım”

Denetmenlerin de dile getirdiği mesleki süreçte eğitim kurumlarında bire bir/yüz yüze iletişim ve etkileşim ortamlarının varlığı etkili kullanıldığında mesleki avantaja aksi durumda ise birçok soruna neden olabilmektedir.

Kişisel Özellikler: Eğitim denetmenlerine göre meslek ve alan bilgisi dışında bazı kişisel özelliklere sahip olmak kendilerini güçlü kılmaktadır. Eğitim denetmenlerinin sahip olması gereken kişisel özellikler içerisinde sırayla empatik davranma, değer yargılarına saygı, sempatik ve esprili olma, özgüven, alçak gönüllük, samimiyet ve güler yüz kavramları öne çıkmaktadır. Bu durumu açıklayan katıımcı görüşlerinden bazıları şöyledir:

“...sempatik bir şekilde olaylara esprili yaklaşarak çözüm üretmeye çalışırım” (D 12)

“...samimiyet ve iyi niyetimi göstermeye çalısıırım” (D 18)

“...uzlaşıcılığım, davranışlardaki netlik ve öğretmenlerle empati kurmak önemlidir" (D 26)

“...öğretmenlerle sosyal açıdan başarılı bir iletişim kurmaya çalışırım” (D 31)

“...öğretmenlerle karşılıklı olarak anlayış içerisinde rehberlik etmeye çalışırım” (D 40)

Yukarıda doğrudan alıntılarda dile getirilen kişisel özellikler genelde sosyal yapı ve özelliklerle birlikte değerlendirilmelidir. Dolayısıyla formelden ziyade daha çok informal yapı ve ilişkilerin etkili olduğu eğitim kurumlarında denetmenlerin teknik bilgiye sahip olmalarının yanı sıra bu tür insani/kişisel davranışlara de sahip olmaları önemlidir.

Teknik Bilgi: Eğitim denetmenlerinin meslek ve alan bilgileri dışında kendilerini güçlü kıldığını düşündükleri özellikler içerisinde teknik bilgi sayılmakta ve bu alan sırayla karar verme, yeterlilik, kavrama ve problem çözme becerisi gibi kavramları öne çıkmaktadır. Bu durumu açıklayan katılımcı görüşlerinden bazıları şöyledir: 
“...kanunun verdiği inceleme ve soruşturma yetkisi ile teklifte bulunma konumundan hareketle kararları etkileme gücü" (D 6)

“...öğretmenlik tecrübemden dolayı taşıdığım yeterlikler" (D 13)

Denetmenlerin belli bir süre öğretmenlik yapan eğitimciler arasından sınav ile atanması sonucunda öğretmenlikte geçen ve edindikleri deneyimleri denetim mesleğine aktarmalarını kolaylaştırmakta ve teknik anlamda denetmenleri güçlendirmektedir.

Objektif Olma. Eğitim denetmenlerinin meslek ve alan bilgisi dışında kendilerini güçlü kıldığını düşündükleri bir diğer kişisel nitelik olarak da objektif olma özeliği dile getirilmektedir. Objektif olma beraberinde hakkaniyete uyma davranışını içermekte ve eğitim denetmenlerinin güçlü yönleri arasında sayılmaktadır. Bu durumu açıklayan katılımcı görüşlerinden bazıları şöyledir:

“...dürüstlük, samimiyet (doğruluk anlamında)," (D 4)

“... güvenilirlik, ön yargısız olmak, tepeden bakmamak,” (D 11)

"...adaletli olmak, yanlışları giderici olmak," (D 22)

“... kasıtlı olan yanlışların yanında yer almamak." (D 30)

Denetim mesleği ve bu mesleği yürüten kişilere yönelik denetlenenler tarafından eleştiri ve olumsuz yargıların varlığına rağmen müfettişlerin hala “...dürüstlük, samimiyet (doğruluk anlamında), "“'... güvenilirlik, ön yargısız olmak, şeklindeki davranışları önemsemeleri anlamlıdır.

\section{Görev Esnasında Etki/Baskı Altında Kalınan Durumlar}

Eğitim denetmenleri mesleklerini yürütürken kurumsal veya yönetsel olarak onların kararlarına etki edebilecek ve baskı altına alabilecek kişi ve kurumların neler olduğu bu başlık altında incelenmektedir. Denetmenlerin görev esnasında etkisi/baskısı altında kaldıklarını düşündükleri durumlar Tablo 4' te sunulmaktadır.

Tablo 4: Eğitim Denetmenlerinin Etkilendikleri Durumlar

\begin{tabular}{ll} 
Ana Temalar & Alt Temalar \\
\hline \multirow{2}{*}{ Üst Yönetimin Baskısı $(n=26)$} & İnceleme. ve sorusturmalar \\
& $\begin{array}{l}\text { Üst yönetimin etkisi } \\
\text { Mevzuat }\end{array}$ \\
\hline
\end{tabular}




\begin{tabular}{|c|c|}
\hline & $\begin{array}{l}\text { Görev yoğunluğu } \\
\text { Zaman baskısı, Mevzuat } \\
\text { Alan dışı soruşturma } \\
\text { Yetki azlığı, Ekonomi } \\
\text { Ulaşım, Grup çalışması }\end{array}$ \\
\hline Meslek Tanımı ve Kapsamı (n=17) & $\begin{array}{l}\text { Özlük hakları, Çalışma } \\
\text { koşulları }\end{array}$ \\
\hline $\begin{array}{l}\text { Kişisel Yetersizlikler ve Önyargılar } \\
(n=11)\end{array}$ & $\begin{array}{l}\text { Bürokratik sosyalleşmeme } \\
\text { Aşırı samimi ilişkiler } \\
\text { Önyargılar } \\
\text { Yetkiyi kullanma, Adam } \\
\text { kayırma, } \\
\text { Her istediğini yaptırabile } \\
\text { düşüncesi }\end{array}$ \\
\hline
\end{tabular}

Tablo 4'te ortaya çıkan temalar incelendiğinde eğitim denetmenlerinin mesleklerini yürütürken onların kararlarını etkileyen ve dolayısıyla baskı altında kaldıklarını düşündükleri durumlar üst yönetimin baskısı, meslek tanımı ve kapsamı, kişisel yetersizlikler ve önyargılar kavramları altında toplanmaktadır.

Üst Yönetimin Baskısı. Eğitim denetmenlerinin üst yönetimin baskısı altında kalması, üst yöneticileri de kapsayan inceleme-soruşturmalar, üst yönetimin etkisi ve mevzuat kavramları şeklinde ifade edilmektedir. Bu durumu açıklayan katılımcı görüşlerinden bazıları şöyledir:

“...müfettişi baskı altında tutan mevzuattır. Mevzuat bazen pratik çözümü engelleyebilmektedir." (D 15)

“...kendi ilinde görev yapmanın getirdiği çevresel baskılar ile siyasi baskılardan söz edilebilir." (D 19)

“...hiyerarşik bir düzende yapılan soruşturmanın üst yöneticilere de uzanması....." (D 24)

“...soruşturmalarda özellikle siyasi, hiyerarşik ve değişik güç odaklarının ciddi baskıları hissediliyor." (D 35)

Eğitim denetmenleri görevlerini yürütürken etkisi ve baskısı altında kaldıkları durumlar genel olarak mevzuattan, kendi ilinde görev yapıyor olmaktan ve soruşturmaların üst yönetimlere uzamasından kaynaklanmaktadır. Etkisi altında kalınan durumların fazlalığı objektifliği, tarafsızlığı, verimliliği olumsuz etkilediği dolaylı olarak dile getirilmektedir. 
Meslek Tanımı ve Kapsamı: Eğitim denetmenlerinin mesleklerini yürütürken etkisi/baskısı altında kaldıkları bir diğer durum olarak da görev tanımı ve kapsamı belirtilmekte ve bu alanda sırayla görev yoğunluğu, zaman baskısı, alan dışı soruşturma, yetki azlığı, ekonomik şartlar, ulaşım, grup çalışması, mevzuat, özlük hakları ve çalışma koşulları gibi kavramlar öne çıkmaktadır. Bu durumu açıklayan katıımcı görüşlerinden bazıları şöyledir:

“...görev yoğunluğu ve zaman baskısı olumsuz etkiliyor" (D 20)

“...alan dışında denetim yapmanın yarattığı yetersizlik durumu ve duygusu..." (D 16)

Eğitim denetmenlerinin görev alanlarının oldukça geniş ve çeşitli olması ve alan dışından denetim yapılması kendilerini olumsuz etkilemektedir.

Kişisel Yetersizlikler ve Önyargılar: Eğitim denetmenlerinin mesleklerini yürütürken etkisi/baskısı altında kaldıkları bir diğer durum olarak kişisel yetersizlikler ve önyargılara dikkat çekilmektedir. Bu durum sırayla adam kayırma, istediğini yaptırabilme düşüncesi, sosyalleşmeden uzak davranışlar, özellikle resmiyet veya bürokratik tutum ve davranışların ötesinde aşırı samimi ilişkiler, önyargılar ve yetkiyi kullanma alanları şeklinde ifade edilmektedir. Bu durumu açıklayan katıımcı görüşlerinden bazıları şöyledir:

“...tanıdık öğretmenler, arkadaşlık ilişsileri ve düşünce yapıları etkili olabiliyor" (D 30)

"...grup halinde çalışma olumsuz etkileyebiliyor" (D 29)

“...müfettişlerin her şeyi bildiği inancı ve onların yanlış yapmayacağı düşüncesi” (D 26)

Denetmenlerin mesleklerini yürütürken yukarıda dile getirilen bu tür tutum ve davranış içerisine girmeleri aslında denetim mesleğini yürüten kişilerin profesyonelleşme ile kişisel beklentiler arasında kaldıklarını göstermektedir.

\section{4. Öğretmenleri Rahatsız Eden Denetmen Davranışları}

Eğitim denetmenlerinin rehberlik, denetim, araştırma, inceleme ve soruşturma görevlerini yerine getirirken sergiledikleri davranışlardan hangilerinin öğretmenleri rahatsız ettiği yine denetmenlerin görüşleri doğrultusunda incelenmekte ve elde edilen bulgular Tablo $5^{\prime}$ te sunulmaktadır. 
Tablo 5: Öğretmenleri Rahatsız Eden Denetmen Davranışları

\begin{tabular}{|c|c|}
\hline Ana Temalar & Alt Temalar \\
\hline $\begin{array}{l}\text { Olumsuz Tutum ve Davranışlar } \\
(\mathrm{n}=43)\end{array}$ & $\begin{array}{l}\text { Kullanılan emredici dil } \\
\text { Ön yargılar } \\
\text { Yapıcı } \\
\text { bulunmama } \\
\text { Eksik yönleri öne çıkirilerde } \\
\text { Mesafeli davranma } \\
\text { Gereksiz tartışmalar } \\
\text { Çokbilmiş tavırlar } \\
\text { Önemsiz detaylara takılma } \\
\text { Baskıcı tavırlar }\end{array}$ \\
\hline Mesleki Yetersizlikler $(n=29)$ & $\begin{array}{l}\text { Ortak mesajlar verememe } \\
\text { Görev alanı dışına çıkma } \\
\text { Şekilcilik } \\
\text { Eski bilgileri tekrarlama } \\
\text { Kendini yenilememe } \\
\text { Profesyonel olunmaması }\end{array}$ \\
\hline İletişim Engelleri $(n=9)$ & $\begin{array}{l}\text { Iletişim eksikliği, } \\
\text { Katı mevzuat }\end{array}$ \\
\hline
\end{tabular}

Tablo 5'te ortaya çıkan temalar incelendiğinde eğitim denetmenlerine göre mesleklerini yerine getirirken öğretmenlerin rahatsız oldukları bazı rol ve davranışlar görülmektedir. Öğretmenleri rahatsız eden denetmen rol ve davranışları sırasıyla denetmenlerin olumsuz tutum ve davranışları, mesleki yetersizlik ve iletişim engelleri başlığı altında sunulmaktadır.

Olumsuz Tutum ve Davranışlar: Eğitim denetmenlerinin olumsuz tutum ve davranışları teması altında sırayla; kullanılan emredici dil, ön yargılar, yapııı eleştirilerde bulunmama, eksik yönleri öne çıkarma, mesafeli davranma, gereksiz tartışmalar, çokbilmiş tavırlar, önemsiz detaylara takılma ve baskıcı tavırlar alt kategoriler olarak öne çıkmaktadır. Bu durumu açıklayan katıımcı görüşlerinden bazıları şöyledir:

“...aşırı bilgiç tavır ve emir verici dil kullanılmaktadır..." (D 4)

“...emredici davranışlar öğretmenleri rahatsız etmektedir" (D 6)

“...oldukça ilgilidir her şeyi ben bilirim tavrı..." (D 18)

“...aşırı detayclık..." (D 10)

“...eleştirel söz ve beden dili kullanma..." (D 11) 
“...olumsuz yönde eleştirel gözle bakmaları, olumlu şeyleri göz ardı edip olumsuzlukları vurgulamaları..."

Doğrudan alıntılar kavramsal düzeyde analiz edildiğinde eğitim öğretim etkinliklerinin niteliğini arttırma ve insani çerçevede etkileşimde bulunma eylemlerine zarar veren işaretler ortaya çıkmaktadır. Bazı denetmenlerin davranışlarında ortaya çıktığı ileri sürülen aşırı bilgiç tavırlar, emredici dil, teferruatçılık, öğretmeni yalnız üreten bir makine gibi görme, yapıcı eleştiride bulunmama, despotça davranışlar, şirinlikler, olumsuzlukları vurgulama gibi sorunlu davranışların bizzat denetmenlerce ifade edilmesi oldukça önemlidir. Eğitim denetmenleri davranışsal açıdan hem kendi öz eleştirilerini yapmakta hem de birlikte çalıştıkları meslektaşlarını eleştirmektedirler. Nitekim son yıllarda denetimin rehberlik merkezli yapılmasına ilişkin ağırlık kazanan eğilimle bir arada olması mümkün olmayan bu gibi davranışların araştırmaya katılan denetmenlerin büyük çoğunluğu tarafından dile getirilmesi denetim sisteminin ve denetmen davranışlarının masaya yatırılması aciliyetine vurgu yapmaktadır.

Mesleki Yetersizlikler: Eğitim denetmenlerinin öğretmenleri rahatsız eden davranışlarından bir diğeri mesleki yetersizlikler teması altıda toplanmakta ve bu tema sırayla ortak mesajlar verememe, görev alanı dışına çıkma, şekilcilik, eski bilgileri tekrarlama, kendini yenilememe, profesyonel olunmaması şeklinde ortaya çıkmaktadır. Bu durumu açıklayan katılımcı görüşlerinden bazıları şöyledir:

"...ölçme değerlendirmede de yapılan hatalar çok ciddi bir etken..." (D 28)

“...bilmediği konularda bilmiş gibi kendini göstermek..." (D 29)

“...sorgulayıcı ve evrak isteyen müfettişlerin sevilmediğini düşünüyorum" (D 12)

Şekilcilik, kendini yenileyememe ve eski bilgileri tekrarlama gibi yetersizliklerin öğretmenlere yol gösterme ve rehberlik yapma konumunda bulunan denetmenlerle ilişkilendirilmesi düşündürücüdür. Uzman oldukları varsayımından hareketle okullardaki sorunlara çözüm üretmekle ve öğretmenlere yol göstermekle görevlendirilen bir meslek grubu mensuplarının sorunun derinleşmesine neden olacak davranışları sergilemeleri son yıllarda yapılan değişimlerin denetim sistemi açısından öze inemediğinin ve isim yenilemekten öteye geçemediğinin bir ifadesi olarak değerlendirilebilir.

İletişim Yetersizliği: Eğitim denetmenlerine göre mesleklerini yerine getirirken öğretmenlerin rahatsız oldukları denetmen rol ve davranışlarının bazıları yetersiz iletişim ve 
katı mevzuattan kaynaklanmaktadır. Bu durumu açıklayan katılımcı görüşlerinden bazıları şöyledir:

“...klasik denetim anlayışı öğretmeni rahatsız etmektedir." (D 32)

“...düzeltme ve geliştirme rolünün oynanması gerekir...” (D 43)

"...yaklaşım, üslup ve kullanılan dil, oluşan iletişim düzeyinden kaynaklanan sıkıntılar..."(D 20)

"...güler yüz olmayışı, olumsuzlukları ön plana çıkarma, insan ilişkilerinde üslupdavranış eksikliği önemlidir" (D 3)

“...eksik aranması, kullanılan üsluplar." (D 4)

Güler yüz, üslup ve empati gibi insanlar arası iletişimin vazgeçilmez kavramlarına en fazla denetmenlerin başvurması gerekirken bu gibi davranışların eksikliğinin bir tema olarak ortaya çıkması öğretmenler açısından denetim sistemine yönelik olumsuz tutumları açıklar niteliktedir.

Belirtilen temaların dışında eğitim denetmenlerinin yaklaşık dörtte biri denetim sürecinin öğretmenlerde bir rahatsızlık oluşturduğunu kabul etmekte ancak bu durumun denetmenlerden kaynaklanmak yerine denetimin doğasında var olduğu ve dolayısıyla öğretmenleri rahatsız eden şeyin denetmen davranışı olmadığı ileri sürülmektedir. Denetim sürecinde öğretmenlerde oluşan mevcut rahatsızlığın denetimin doğasından ve öğretmenlerdeki olumsuz algıdan kaynaklandığını vurgulanmaktadır. Bu durumu açıklayan katılımcı görüşlerinden bazıları şöyledir:

"...doğrudan ilgili değildir" (D 23)

“...denetlenen ve denetleyen arasında mesleğin gereği oluşan bir durumdur" (D 26)

"...bu durum müfettiş davranışından ziyade denetimin doğasından kaynaklanmaktadır." (D 30)

“...doğası gereği insan denetlenmekten hoşlanmaz, bu nedenle müfettişe yönelik tutum olumsuzdur, çevreden duyulan müfettiş hikâyeleri de etkilidir" (D 42)

Insanların doğal olarak denetlenmekten hoşlanmaması ve kendi yaptıklarının dışarıdan birisi tarafından kontrol edilmesinden tedirgin olması kabul edilebilir bir olgudur. Var olan bu olumsuz anlayışın düzeltilmesinde ve denetimin geliştirici yönünün öne çıkarılmasında 
denetmen davranışları belirleyicidir. Olumsuz bir yargının düzeltilmesi sürecinde oldukça önemli bir işleve sahip olması gereken meslek grubunun endişeye, tedirginliğe ve strese neden olduğunun bizzat bu meslek grubu üyelerince seslendirilmesi altı çizilmesi gereken önemli sorunlar arasında sayılabilir.

\section{5. Örneklik Sergilenmede Gelişime Açık Alanlar}

Eğitim denetmenlerinin örneklik sergileme aşamasında gelişime açık alanları bir anlamda kendi ifadeleri ile intiyaç duydukları eğitim başlıklarıdır. Denetmenlerin görev esnasında gelişime açık alanları Tablo 6’ da sunulmaktadır.

Tablo 6: Gelişime Açık Alanlar

\begin{tabular}{ll}
\hline Ana Temalar & \multicolumn{1}{c}{ Alt Temalar } \\
\hline Mesleki Rehberlik ( $\mathrm{n=39)}$ & Sınıf/okul yönetimi \\
& Öğrencilere yaklaşım \\
& Toplumsal kabul \\
& Alan uzmanlığı \\
& Branşlaşma \\
& Öğretim yöntemlerini kullanma \\
& Protokol kuralları \\
& Öğretim programları \\
& Mesleki yeterlik \\
\hline Model Olma ( $\mathrm{n}=21)$ & Temsil kabiliyeti \\
& Eğitimsel rehberlik \\
& Sigara içme \\
& Kitap okumama \\
& Dış görünüm \\
\hline Yenilik ve Değişim ( $\mathrm{n}=19)$ & Gelişmeleri takip etme \\
& Kendini geliştirme \\
\hline
\end{tabular}

Tablo 6'te ortaya çıkan temalar incelendiğinde eğitim denetmenlerine göre mesleki rehberlik, model olma, gelişime ve değişime açık olma şeklinde ifade edilmektedir. Öğretmenlerin yarıya yakını mesleki rehberlik konusunda eğitim ihtiyacı içerisinde olduklarını belirtirken yaklaşık beşte biri öğretmenlere model olma ve yenilik-değişim konularında bilgi ihtiyacı içerisinde olduğunu ifade etmektedir.

Mesleki Rehberlik: Eğitim denetmenlerinin gelişime açık alan olarak gördükleri mesleki rehberlik teması altında sırasıyla sınıf /okul yönetimi, öğrencilere yaklaşım, toplumsal kabul, alan uzmanlığı, branşlaşma, öğretim yöntemlerini kullanma, protokol kuralları, öğretim programları, mesleki yeterlik alt kategorileri ön plana çıkmaktadır. Bu durumu açıklayan katılımcı görüşlerinden bazıları şöyledir:

"...mesleki yeterlilik konuları bunun başını çekmektedir..." (D 1) 
“...ders programlarına hakim olamama..." (D 17)

“...alan uzmanlığı konusunda eksikliğimiz olduğunu düşünüyorum, branş dışı denetim yetersizliğe yol açmaktadır..." (D 13)

“...rehberlik yapan müfettişle öğretmenin aynı branştan olmamaları yetersizliklere neden olmaktadır" (D 20)

“...öğretimde kullanılacak yöntem ve teknikleri uygulama boyutunda tanıtma ve öğrenci tanıma tekniklerini kullanmakta bazı yetersizler vardır" (D 21 )

Model Olma: Eğitim denetmenleri model olmayı ikinci gelişime açık alan olarak görmekte bu tema altında sırayla temsil kabiliyeti, eğitimsel liderlik, sigara içme, kitap okumama, dış görünüm kavramlarında öne çıkmaktadır. Bu durumu açıklayan katılımcı görüşlerinden bazıları şöyledir:

“...öğretim yöntem ve teknikleri,.... "(D 7)

“...teknoloji kullanmada yetersizlik,..” (D 9 )

“...rutinleşmiş, kısırlaşmış bir iş anlayışı ..." (D 2)

“...kendini geliştirme ve eğitim liderliği açısından eksiklikler var" (D 14)

“...sigara içmeleri, kitap okumamaları ve kendilerini geliştirmemeleri..." (D 11)

Denetmenlerin kurum ve kişilere etkili ve yeterli rehberlik ve denetim yapabilmesi çağımızın gerektirdiği değişim ve gelişmelerden haberdar olması, o konularda yeterli donanıma sahip olması ile mümkündür.

Yenilik ve Değişim: Eğitim denetmenleri bu tema altında sırayla gelişmeleri takip etme, kendini geliştirme kavramları öne çıkmaktadır. Bu durumu açıklayan katılımcı görüşlerinden bazıları şöyledir:

“... güncel bilgilere sahip olmalı..." (D 9)

“...kendini yenileyememe" (D 42)

Eğitim müfettişlerinin dile getirdikleri yenlik ve değişim konularındaki eksikliklerin müfettiş olarak kurumsal anlamda giderilmesini beklemekten ziyade her yerde ve her zaman eğitim, yaşam boyu öğrenme anlayışlarının gereği ve sonucu olarak müfettişler bilgi kaynaklarına ulaşma yol ve yöntemleri ile güncel bilgiye erişmede kendilerini sorumlu ve zorunlu hissetmektedir. 


\section{SONUÇLAR VE TARTIŞMA}

Araştırma sonucunda eğitim denetmenliği mesleğinde iletişim ve liderlikle ilgili kavramlar ön plana çıkmaktadır. Denetmenlerin büyük çoğunluğunun bu kavramlara vurgu yapması sahip olunması gereken ve eksikliği görülen davranışlara ilişkin önemli bilgiler sunmaktadır. Özellikle son yıllarda denetimden rehberliğe doğru anlayış değişikliğinin yaşandığı bir ortamda bu kavramların vurgulanması anlamlıdır.

Eğitim denetmenlerinde olması gereken nitelikler ve sergilemeleri gereken davranışlar iletişim becerisi, kişilik özellikleri ve tarafsızlık/önyargısız olma kavramları çerçevesinde şekillenmektedir. Meslek ve alan bilgisi dışında kendilerini güçlü kıldığını düşündükleri nitelikler olarak sosyal beceriler, kişisel özellikler, tarafsızlık ve teknik bilgi kavramlarının altının çizilmesi Rutrough, $(1967,249)$ Carron ve De Grauwe $(1997,49)$ ve Oliva ve Pawlas $(2004,25)$ 'in çalışmaları ile paralellik göstermektedir. Denetmenlerin başarısı sahip oldukları teknik bilgi ve yeteneklerden çok kurdukları insan ilişkilerine bağlı olarak değerlendirilmekte, insan ve grup davranışlarını yorumlamadaki beceriler ön plana çıkmaktadır. "Denetim" yerine "işbirliği", "takım çalışması", "demokrasi" ve "rehberlik" gibi kavramlar vurgulanmaktadır. Bu noktada samimiyet, empati, içtenlik, dürüstlük, sadakat, arkadaşlık, yardımseverlik, kolaylaştırıcılık, yenilikçilik, etkileyicilik, birlikte çalışma, sabır, ince bir mizah duygusu, ikna yeteneği, mesleki şevk gibi davranışlara atıfta bulunulmaktadır.

Eğitim denetmenlerinin sahip olunması gereken ve güçlü kılan davranışlar kapsamında "kişisel özelliklerin" sıkça vurgulanması, bu bağlamda hoşgörü, empati, anlayış gösterme ve güven kavramlarına değinilmesi, teknik yeterlik kadar insani yeterliklerin de önemsenmesi Rutrough $(1967,249)$ 'un geçen yüzyılın ikinci yarısında ifade ettiği “20. yüzyıın başlarında eğitimin ve öğretmenlik mesleği bir takım öğretimsel kuralların harfiyen yerine getirilmesiyle başarılı olunabilecek bir bilim alanı olarak algılanmakta iken yüzyılın sonlarına doğru insan ilişkileri ve grup iklimine bağlı olarak kendine has nitelikleri olan bir sanat olarak düşünülmeye başlanmıştır" şeklindeki düşünceleri ile desteklenmektedir.

Eğitim denetmenleri görevlerini yerine getirirken öğretmenleri rahatsız eden bazı davranışlar sergilediklerini ifade etmektedir. Öğretmenleri rahatsız eden denetmen davranışlarından olumsuz tutum ve davranışlar, mesleki yetersizlikler, denetimin doğasından kaynaklanan unsurlar ve iletişim eksikliği bulgusu benzer araştırma (Lillis, 1992, 5; Badavan, 1994, 39; UNESCO, 2007; 13; Kayıkçı ve Şarlak, 2009; Yavuz ve Yıldırım, 2009; Seylim, 2009; Aksu ve Mulla, 2009; Yaman, 2009, 115; Samancı, Taşçıoğlu ve Çetin, 2009) sonuçları ile 
desteklenmektedir. Bu anlamda denetmenlerin mevzuat bilgisi dışında öğretmenlere rehberlik edebilecek niteliklere ve davranışlara sahip olması bulundukları konumun bir gereğidir. Öğretmenlerin genel anlamda denetim sistemin yönelik sahip olduğu olumsuz düşünceleri denetmenlerin tavır ve davranışlarından bağımsız değerlendirmek mümkün değildir. Denetmenlerin denetim esnasında sergilediği davranışlar ve öğretmenlere yönelik sahip oldukları tutumlar ile bu tutum ve davranışlara kaynaklık eden davranışlar mevcut denetim ikliminin şekillenmesi ve algılanması ile yakından ilgilidir

Eğitim denetmenlerinin gelişime açık alanları olarak mesleki rehberlik, model olma, yenilik ve değişim temalarının ön plana çıkması Carron ve De Grauwe $(1997,36)$ 'in çalışmaları ile paralellik göstermektedir. Carron and De Grauwe' e göre de ülkelerin gelişmişlik düzeyinden bağımsız olarak denetmenlerce gerçekleştirilen denetim etkinliklerine yönelik bir hoşnutsuzluk hissedilmekte, niteliği yükseltmenin yolu olarak formal süreçler yerine okul düzeyinde hakim olan informal iletişim kanalları gösterilmektedir. Ayrıca Koehn and Goens $(1977,585)$ 'in çalışmaları da elde edilen bulguları destekler niteliktedir.

\section{KAYNAKÇA}

Aksu, M.B. ve Mulla, E. (2009). ilköğretim Denetmenlerinin insan ilişkileri Yeterlikleri, 1. Uluslararası Katılımlı Ulusal Eğitim Denetimi Sempozyumu, Ankara: 22-23 Haziran.

Badavan, Y. (1994). Innovative Behaviour and Primary School Supervisors In Turkey, Hacettepe Üniversitesi Eğitim Fakültesi Dergisi, 10, 31-41

Carrón, G. and De Grauwe, A. (1997). Current issues in supervision: a literature review, Trends in school supervision, International Institute For Educational Planning, UNESCO.

EARGED (2002). Milli Eğitim Bakanlığı, Eğitimi Araştırma ve Geliştirme Dairesi Başkanlığı Yayınları Okulda Performans Yönetimi Modeli. Ankara.

Kautzmann, L. N. (1990). Clinical Teaching: Fieldwork Supervisors' Attitudes and Values, Tbe American\}aurnal a/Occupational Therapy, 44 (9), 835-838.

Kayıkçı, K. ve Şarlak, Ş. (2009). ilköğretimde Denetimin Etkili İ̧̧leyişini Zorlaştıran ve Zayıflatan Örgütsel Engeller, 1. Uluslar arası Katılımlı Ulusal Eğitim Denetimi Sempozyumu, Ankara: 22-23 Haziran.

Koehn, J.J. and Goens, G.A. (1977). The Talent We Nourish: A Word for Supervisor, Educational Leadership, May, 585-588.

Lillis, K, M. (1992). Improving basic education: preconditions for successful inspection and supervision - implications for training, IIEP research and studies programme Increasing and improving the quality of basic education, International Institute for Educational Planning, U N E S C O.

OIG. (2005). Office of Inspector General (OIG): Promoting Integrity in Federal Education Programs for 25 Years U.S. Department of Education Office of Inspector General. 
Oliva, P.F and Pawlas, G.E. (2004). Supervision For Today's Schools. New York: Longman.

Patrick, E. A. (2009). Strategies For Improving Supervisory Skills For Effective Primary Education In Nigeria, Educational Journal of Counselling, 2 (2), 235-244.

Resmi Gazete. (1993a). Milli Eğitim Bakanlığı Teftiş Kurulu Tüzüğü, 19.2.1993 Tarih ve 21501 Sayılı Resmi Gazete.

Resmi Gazete. (1993b). Milli Eğitim Bakanlığı Teftiş Kurulu Yönetmeliği. 3.10.1993 Tarih ve 21717 Sayılı Resmi Gazete.

Resmi Gazete, (2011b). Milli Eğitim Bakanlığının Teşkilat ve Görevleri Hakkında Kanun Hükmünde Kararname, 14 Eylül 2011 Tarihli ve 28054 Sayılı Resmî Gazete.

Resmi Gazete. (2011a). Milli Eğitim Bakanlığı Eğitim Müfettişleri Başkanlıkları Yönetmeliği. 24.06.2011 Tarih ve 27974 Sayılı Resmi Gazete.

Rutrough, J.E. (1957). The Supervisor's Role In Personel Administration, Educational Leadership, December, 249-255.

Samancı, O., Taş̧̧ığlu, N. ve Çetin, İ. (2009). Ilköğretimde Görev Yapan Öğretmenlerin Müfettişlerden Beklentileri, 1. Uluslar Arası Katılımlı Ulusal Eğitim Denetimi Sempozyumu, Ankara: 22-23 Haziran.

Sergiovanni, T.J. (1977). Reforming Teacher Evaluation: Naturalistic Alternatives, Educational Leadership, May, 602-607.

Seylim, E. (2009). MEB ilköğretim Müfettişleri Başkanlıkları Rehberlik ve Teftiş Yönergesinin Bazı Maddelerinin Uygulanması Hakkında Ilköğretim Öğretmenlerinin ve Müfettişlerinin Görüşleri, 1. Uluslar Arası Katılımlı Ulusal Eğitim Denetimi Sempozyumu, Ankara: 22-23 Haziran.

UNESCO. (1999). Quality Education Through School Based Supervision and Support, Trends In School Supervision, International Institute For Educational Planning, UNESCO.

UNESCO. (2007). Roles and Functions of Supervisors, Reforming School Supervision for Quality Improvement, International Institute For Educational Planning, UNESCO.

Yaman, E. (2009). Müfettişlerin Rehberlik Rollerini Rehber Öğretmenler Değerlendiriyor, International Online Journal of Educational Sciences, 1 (1), 106-123.

Yavuz, M. ve Yıldırım, A. (2009). Ilköğretim Müfettişlerinin seçimi ve Yetiştirilmelerine ilişskin Öğretmen Görüşleri, 1. Uluslar arası Katılımlı Ulusal Eğitim Denetimi Sempozyumu, Ankara: 22-23 Haziran.

Yıldııım, A. ve Şimşek, H. (2005). Sosyal bilimlerde nitel araştırma yöntemleri, (5. bs.), Ankara: Seçkin. 


\section{ABSTRACT}

Educational supervision in schools of Turkey has been fullfilled by twofold one of which was carried out centrally by simply named supervisor of ministry and other was done by district supervisors charged in provinces. It has been long debated why supervisons of education constructed twofold and usually overlapped the roles of supervisors. Although the name of supervisors has changed and their span of duties has expanded recently, they have nearly done the similar jobs of supervisions without any philosophical and theoretical transformation in reality. They have been charged of guiding, service training, supervising, evaluating, investigating and researching for all educational institutions, even their span of responsibilities could be expanded for all institutions if they are charged by governor of the cities.

The researches that were carried out at home and in the world (Lillis, 1992, 5; Badavan, 1994, 39; UNESCO, 2007, 13; Kayıkçı ve Şarlak, 2009; Yavuz ve Yıldırım, 2009; Seylim, 2009; Aksu ve Mulla, 2009; Yaman, 2009, 115; Samancı, Taşçıoğlu ve Çetin, 2009) alleged that teachers are mostly unsatisfied of supervisors' behaviour when they face with teachers at schools for supervisions. Since this dissatisfaction somewhat related inherently the profession of supervision as well as sometimes caused by unprofessionalized moods and behaviours of supervisors. Supervision is defined theoretically to help teachers to do their jobs better. Better performance and achievement of teaching in this sense could only been performed by the help and support of professionals and this is called guidance instead of supervision recently. Teachers are in need of guidance how to do teaching better and what alternative methods of teaching could be preferred in different settings more than simply controlling them whether they do their jobs proper to written rules.

\section{Research Design}

The purpose of this study is to define behaviours of supervisors while performing their tasks in provinces. It was included 47 educational supervisors, and qualitative research design of phenomenology was employed in the research. The data was collected from the volunteer supervisors who were in charged of different provinces in Turkey via interview form and made descriptive and content analysis. Data were exposed to content analysis by two independent researchers and findings were presented as themes and sub categories. It employed a qualitative research method of phenomenology to collect and analyse the interpretations and meanings of supervisors due to the interpretive, meaning-making nature of this study based on the philosophical assumption that research is socially constructed activity and the goal of research is an understanding of a particular situation or context, highlighting the concern about the situatedness of knowledge (Snape and Spencer, 2003; Yıldırım ve Şimşek, 2008). Inductive content analysis was used to analyze the data obtained from this study. Written document were coded and themes were appeared in the final stage of coding, then final themes were tried to be interpreted comparing and contrasting with de facto findings of similar studies. 
The concepts of validity and reliability in qualitative research design have been critisized and found dogmatic as a result of positivist hypothetical deductive reasoning, thus credibility and transferability are more common concepts preferred by qualitative researchers (Corbin \& Strauss, 2008). Moreover, the related literature was examined to create a contextual frame, procedures were explained clearly in detailed, all of the data were written without any interpretation, raw data and coded data have been preserved by the researcher and other researchers are welcome to examine.

\section{Findings and Conclusion}

It was concluded that concepts related with communication and leadership came into forefront. Due to the fact that supervisors have primarily emphasized on such concepts, these are the behaviours that supervisors should adapt first while doing their tasks. It is meaningful to have stressed communication and leadership when there is tendency towards guidance based supervision from control based supervision recently. It was appeared that competence of communication, personal qualification, objectivitive and unprejudiced attitudes were mostly prefered qualifications of supervisors. It has also been appeared that "cooperation", "teamwork", "democracy" and "guidance" were mostly underlined words instead of "supervision" and "inspection". Sincerity, emphaty, trustwortiness, loyalty, facilitativeness were the concepts that were implied as modern way of supervision. Contrary to such positive and encouraging attitudes and behaviours of supervisors when to face with teachers, there are also some negative settings that has been caused by supervisors also. Supervisional insufficiencies, nature of supervision, lack of communication were basic points that has been highlighted similar studies (Lillis, 1992, 5; Badavan, 1994, 39; UNESCO, 2007; 13; Kayıkçı ve Şarlak, 2009; Yavuz ve Yıldırım, 2009; Seylim, 2009; Aksu ve Mulla, 2009; Yaman, 2009, 115; Samancı, Taşı̧ığlu ve Çetin, 2009) and caused negative feelings and attitudes over teachers. 